\title{
Fish aggregating devices (FADs): good or bad fishing tools? A question of scale and knowledge
}

\author{
FOREWORD: Tahiti International Conference "Tuna Fisheries and FADs", November 2011
}

\author{
Marc TAQUET $^{\mathrm{a}}$
}

Ifremer, UMR-EIO 241, Labex Corail, Ifremer Pacific Center, BP 7004, Taravao, Tahiti, French Polynesia

\begin{abstract}
It is estimated that fish aggregating devices (FADs) are now used for over $40 \%$ of world tropical tuna catches, making this technique a major phenomenon for high seas fisheries worldwide, and one that has experienced great expansion over the past three decades. The question of whether the FAD is a good or a bad tool for the exploitation of marine resources depends on many parameters. To respond to this question, it is necessary to distinguish different scales of exploitation (artisanal vs. industrial) and various types of FADs (anchored vs. drifting), but it is also very important to gather more data and conduct further research on this topic to gain a better understanding of the phenomenon and of its impacts. As such, twelve years after the first international conference devoted to FADs, which was held in Martinique (French West Indies), a new multi-scalar global assessment of FAD fisheries development and a review of the progress of research in this field was deemed vital. The latest international conference, "Tuna Fisheries and Fish Aggregating Devices", was held in Tahiti in November 2011, and it was an event that welcomed nearly 150 conference attendees from 40 different countries, three ocean regions, and the Mediterranean. This is an analysis of the relevant literature gathered by the author in the bibliographic database FADBASE. Then, the major issues already addressed by the scientific community are set out, and gaps and research priorities are highlighted for anchored and drifting FADs management.
\end{abstract}

Keywords: Fish aggregating devices / Tuna fisheries / FAD history / FAD bibliography

\section{Introduction}

"The Hippurus, when they behold anything floating in the waves, all follow it, closely in a body, but especially when a ship is wrecked by the stormy winds, finding Poseidon terribly unkind... And for the Hippurus, men may contrive other devices and without the wreck of ships pursue their prey... The fishermen gather reeds and tie them together in bundles which they let down into the waves and underneath they tie a heavy stone by way of ballast. All this they let sway gently in the water; and straightway the shade-loving tribes of the Hippurus gather in shoals and linger about delightedly rubbing their backs against the reeds. Then the fishers row to them to find a ready prey, and bait their hooks and cast them, and the fish seize them, hastening therewith their own destruction. Even as a hunter excites with meat his dogs to the warfare of the chase, waving among them a piece of game, and the dogs in a frenzy of appetite with ravenous rage run emulous one before the other and look to the man's hand to see where he will throw it, and strife of teeth arises: so the fishes rush readily

Tunas and other species associated with FADs

a Corresponding author: marc.taquet@ifremer.fr upon the hooks. And easily, if active, thou shalt catch and land them one after the other; for they are more eager than the fishermen themselves and by their own folly hasten their doom." (Oppian ${ }^{1} 200 \mathrm{AD}$ - Halieutica).

This bibliographic citation and its associated text is proof that Ancient Greeks and Romans were already aware of the aggregative behaviour of pelagic fish, such as dolphinfish (Coryphaena hippurus) and used this knowledge to improve their fisheries (Taquet et al. 2011). Halieutica is a remarkable didactic poem of 3506 verses in five songs written by the young Greek poet Oppian, who was born in Anazarbe, Cilicia (a Roman province at the time, now located in southern Turkey). The first two songs are dedicated to the description of many marine species, including 122 fish. The other three concern the art of fishing. There are several translations of this work, including J. Jones' English translation (1722), and J.M. Limes' French translation (1817). Since Halieutica in the 2nd century, no further literature on FADs appeared until the early 1960s. However, fishing around natural floating objects and the use of anchored FADs are methods that did not disappear between these two periods: FADs were deployed

\footnotetext{
Oppian, Halieutica, translation by A.W. Mair, Loeb Classical Library, London, Heinemann, 1963.
} 
for dolphinfish (Coryphaena hippurus) fishing in the 14th century in the Mediterranean (Morales-Nin et al. 2000) and in the 18th century in Malta particularly (Galea 1961). Beyond the Mediterranean, the use of anchored FADs has been well documented in Indonesia (with the rumpon aggregating devices), Malaysia (the unjang) and the Philippines (the payaos), (Bergstrom 1983), where traditional rafts anchored in coastal zones have been used since the early 20th century to aggregate and exploit small pelagic fish (Anderson and Gates 1996). In the Philippines, tuna fishing began in the 1930s, but it was not until 1974, within the framework of an FAO project, that it truly developed with the arrival of the first two experimental tuna purse seiners. During this period, fishers discovered the effectiveness of the Philippine payaos previously used in coastal areas to concentrate tuna (Marcille and Bour 1981; Dickson and Natividad 2000). FAD use subsequently spread to all oceans, which led to a range of different experiences, and devices, which were made from natural materials (primarily bamboo). One of the first modern FADs (based on manmade products and with tuna as the main target species) was anchored in deep water off Hawaii, in 1977. This initial experiment was followed by the deployment of other FADs in the South Pacific (French Polynesia: first FAD in 1981), Atlantic Ocean (in Martinique in 1982) and Indian Ocean (in the Maldives in 1980 and Mauritius in 1982).

In the late 1950s, the US purse-seiner fleet began its activity in the eastern Pacific by gradually replacing the pole and line fleet that had been operating in this region for several decades (Hall 1998). Therefore, purse-seiners began to occasionally fish the tuna associated with natural wrecks. The deployment of artificial drifting FADs (set voluntarily for fishing purposes) in this region began in the late 1980s. Between 1987 and 1990, 10\% of purse seine "sets" on floating objects were made on drifting artificial rafts, a percentage which rose to 30\% in 1992 and 80\% in 1998 (Lennert-Cody and Hall 2000). In the eastern Atlantic, the first pole and line boats exploited tropical tuna in 1954, with Basque and Breton fishers who operated in the Dakar zone (Fonteneau 1973). Tuna purse seiners arrived in this area in 1964 (Pianet 1973) but their activity around floating objects (natural or artificial rafts) remained relatively marginal until the late 1980s. From this date onwards, the use of artificial drifting FADs equipped with tracking devices continued to grow in the Atlantic, as it did in all other oceans (Fonteneau et al. 2000). In the Indian Ocean, the first seining tests were conducted in the early 1980s, and development of the tuna purse-seiner fleet began in 1984 (Stéquert and Marsac 1991). Since then, development has been mainly directed towards the use of artificial drifting FADs. Fonteneau et al. (2000) estimate that there are tens of thousands of drifting FADs deployed worldwide by industrial purse-seiners. Anchored FADs are also used by local artisanal fleets in the Pacific (Desurmont and Chapman 2000; Holland et al. 2000; Kakuma 2000), Indian (Tessier et al. 2000) and Atlantic Oceans (Reynal et al. 2000) and the Mediterranean Sea (Morales-Nin et al. 2000). In most of these areas, the devices are also frequented by both small-scale fishing vessels and recreational fishers.

Twelve years after the first international conference on tuna fisheries and FADs in 1999 (Martinique, French West Indies)

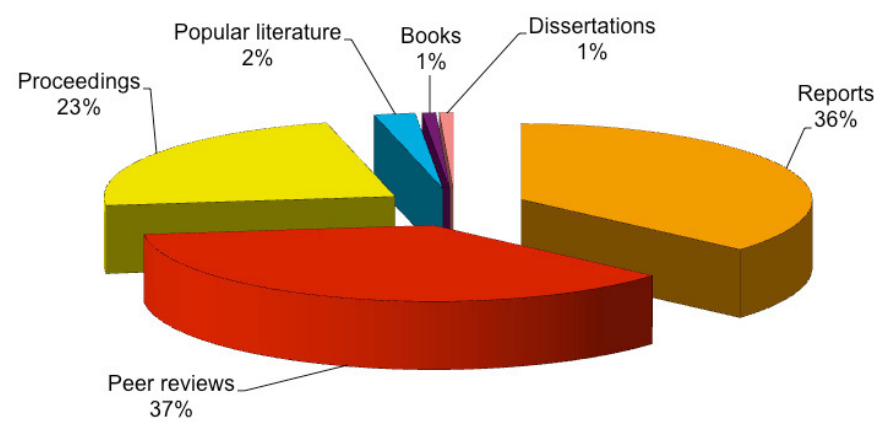

Fig. 1. Number of references $(\%)$ recorded in our FADBase by document category, $n=658$ references.

(Le Gall et al. 2000a), a need was identified to carry out a new global assessment of FAD use by artisanal and industrial tuna fisheries (Taquet et al. 2011). To this end, a new international conference entitled "Tuna Fisheries and FADs" was organized in Tahiti, French Polynesia, in November 2011. As a foreword to the conference, the present article has two aims: (i) to provide an overall description of the available literature (in 2011) on FADs; and (ii) to present the main conclusions and research priorities from the Tahiti FADs Conference.

\section{Literature available on FADs}

The literature search method and the keywords used are as described in (Dempster and Taquet 2004). The Web of Science ${ }^{\circledR}$ is a cited references tool for scientific articles, which has greatly improved online bibliographic searches.

However, most grey literature (e.g., scientific and technical reports, conference proceedings) is not accessible by this method. For the technical documents, a significant proportion of new references (over 2004), were obtained via the digital library of the Secretariat of the Pacific Community (SPC). After reading the documents, the selected references were entered into a Microsoft Excel ${ }^{\circledR}$ table, so as to create a new bibliographic database, which was named "FADBase 2011" and is composed, firstly, of four major identification fields (Year; Authors; Title; Journal) and, secondly, 12 descriptive fields (Type, Submitted refereed/or not, Country, Region, Species, Period, Anchored/Drift, Natural/Artificial, Approach, Main Topic, Methodology, Science). This database is available to download at the following address: http://wwz.ifremer.fr/ cop/Peche

FADBase 2011 contains 658 references on at least one aspect relating to the overall theme of "Tuna Fisheries and FADs - aggregative phenomenon".

Articles in scientific journals comprise 37\% (241), which is almost equivalent to that of scientific and technical reports at $36 \%$ (240). Publications in conference proceedings comprise nearly a quarter $(23 \%, 149)$ of FADBase (Fig. 1). The remaining $4 \%$ is divided between popular articles, student dissertations and theses (Ph.D., Masters, Technical degrees) and books. Peer-reviewed articles in scientific journals are much more accessible than technical reports, which are rarely referenced. Therefore, FADBase is more likely to be closer to complete in the peer-reviewed category than in the others. 


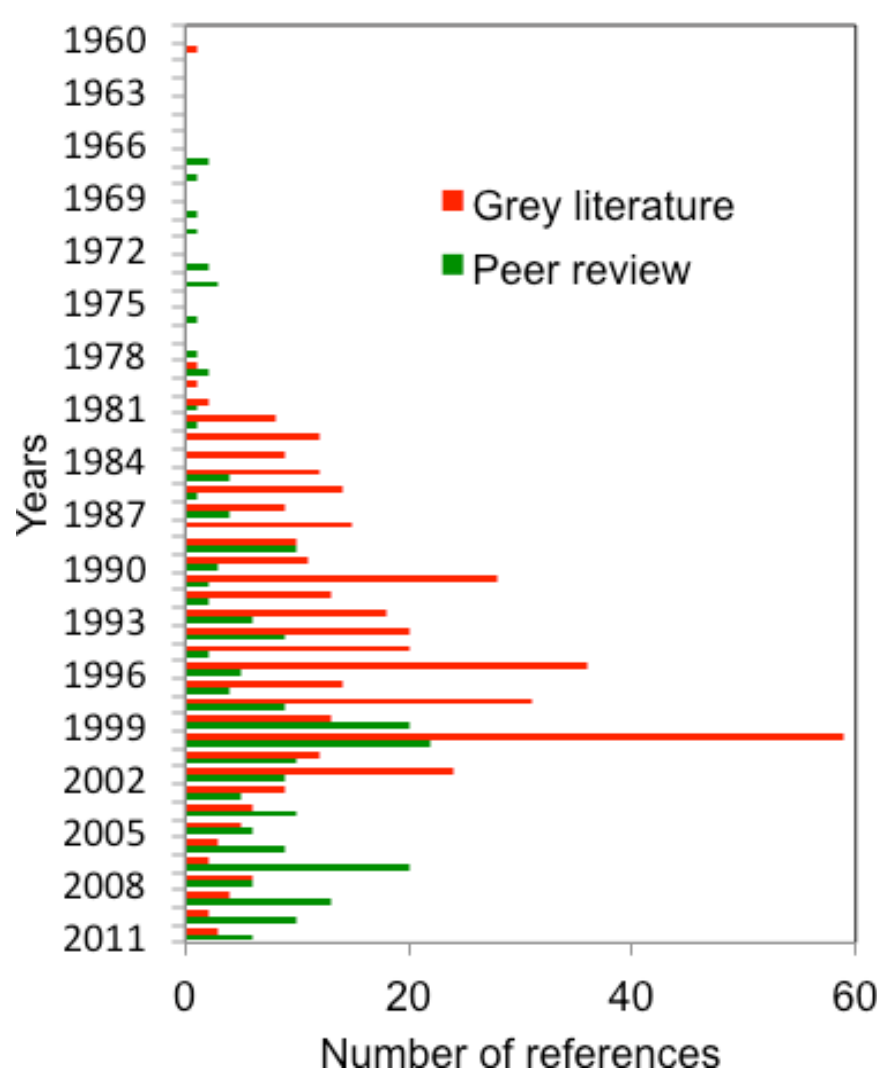

Fig. 2. Long-term changes in the number of articles dealing with FADs, shown separately by document category, between 1961 and 2011.

When comparing the overall proportion of grey literature $(66 \%)$ to scientific indexed articles $(34 \%)$, the imbalance is very pronounced. This is mainly due to the large number of papers published in conference proceedings, which were not classified as peer-reviewed, although they were often subject to selection by a scientific committee and to a pre-publication revision/correction process. This is particularly the case for articles published in 2000 in the "Tuna Fisheries and FADs" conference proceedings (Le Gall et al. 2000b).

Apart from the two aforementioned French and English translations of Halieutica, the first FADBase reference dates back to 1961. Figure 2 shows the distribution of the number of references for the two types (grey literature reports and indexed peer-reviewed articles) over the period 1961 to 2011. This distribution shows a sharp increase in the number of reports published in the early 1980s, which corresponds almost exactly to the launch of many modern anchored-FAD projects (built with man-made components) in the Pacific Ocean (Hawaii, Guam, Palau, Samoa, Mariana Islands, Rarotonga, Tahiti, Australia and New Zealand); the Caribbean (Guadeloupe, Martinique, Virgin Islands, San Juan), and the Indian Ocean (Maldives, Seychelles, Sri Lanka, Comoros, Mauritius, Zanzibar). At the same time, some other attempts were noted in the eastern Atlantic, particularly off the coast of Nigeria. In the framework of several conferences/working groups on tropical artisanal fisheries during this period, many experts recommended that fishery managers develop anchored
FADs to reduce the fishing pressure on reef resources, which were starting to show signs of overexploitation in several areas. Such was the case at the conference on "Environment Management and Economic Growth in the Smaller Caribbean Islands (1979)". Soon afterwards, the Gulf and Caribbean Fisheries Institute (GCFI), in the framework of their 36th annual conference, highlighted the need to use anchored FADs to guide artisanal fisheries to large pelagic fish. The success of the first anchored-FAD projects facilitated the dissemination of information. During the Symposium on "Artificial Reefs and Fish Aggregating Devices as Tools for the Management and Enhancement of Marine Fishery Resources", held in Colombo, Sri Lanka, Preston (1991) states that the good results on FADs obtained in Hawaii and the data on payaos in the Philippines have favoured the introduction and development of such devices in the Pacific. SPC Fishery experts have also played an important role in supporting this type of fishing through various programmes and training projects.

Figure 2 also reveals a significant peak in the publication of grey literature in 2000. This peak is clearly explained by the various articles published following the international conference "Tuna Fisheries and FADs" held in Martinique: 48 articles were published in the conference proceedings and eight in a special issue of Aquatic Living Resources journal. The significant decrease in the number of reports published after 2000 may be partially due to the fact that the bilingual SPC FAD Information Bulletin (or DCP Bull. Information in French) ceased publication after 1998: this bulletin accounts for 30 FADBase references between 1996 and 1998.

There are also a good number of "peer" scientific articles in 2007 due to the publication of a special issue of Aquatic Living Resources dedicated to the results of the FADIO European project (Dagorn et al. 2007). The production over the whole 1961-2011 period fluctuated from year to year and the downward trend that has been noted since 2009 has yet to be confirmed. One possible explanation for the chaotic aspect of the temporal distribution of publications is that FADs are fishing or research tools that are not easily accessible. This is particularly true for drifting FADs. Studying FADs at sea through experimental approaches (e.g., fisheries experiments, fish tagging or acoustic survey) requires heavy equipment (including research vessels). These research projects are difficult and time-consuming to implement; they usually last several years (in general, 3-4 years) and the results are often published in one work at the end of the field phases.

References on anchored-FAD studies dominate (Fig. 3), representing $66 \%$ of FADBase (432 ref.). This proportion is divided into 130 indexed scientific articles and 302 other publications including reports and conference proceedings. References on drifting FADs represent less than $25 \%$ of FADBase. This low number may seem a paradox, as the study of drifting FADs is considered extremely important given their potential impacts on untargeted marine resources (and incidental catches). However, this number of references confirms the aforementioned issue of the immense difficulty involved in accessing drifting FADs, both at the spatial and temporal level.

Regarding the different thematic areas (Fig. 4), the largest group of the references in FAD literature concerns the "description of FAD projects" (32\% - 209 ref.) and mainly 


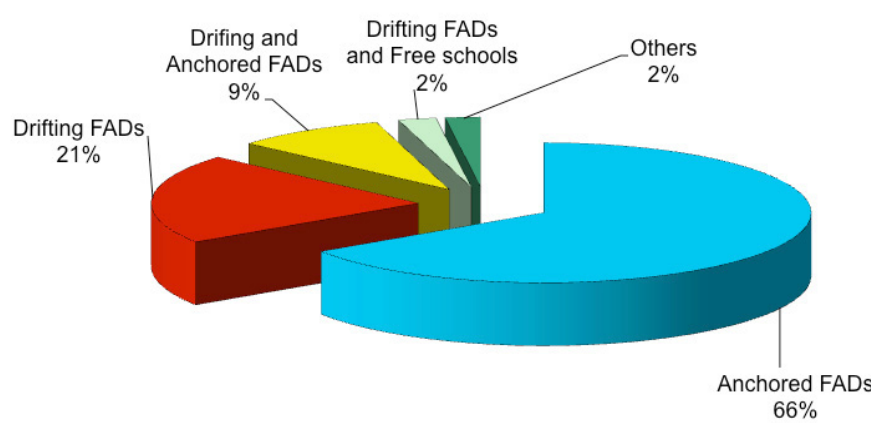

Fig. 3. Number of articles (\%) dealing with FADs by fish school type, highlighting the importance of the articles related to anchored FADs (schools aggregated around anchored FADs, around drifting FADs, etc.).

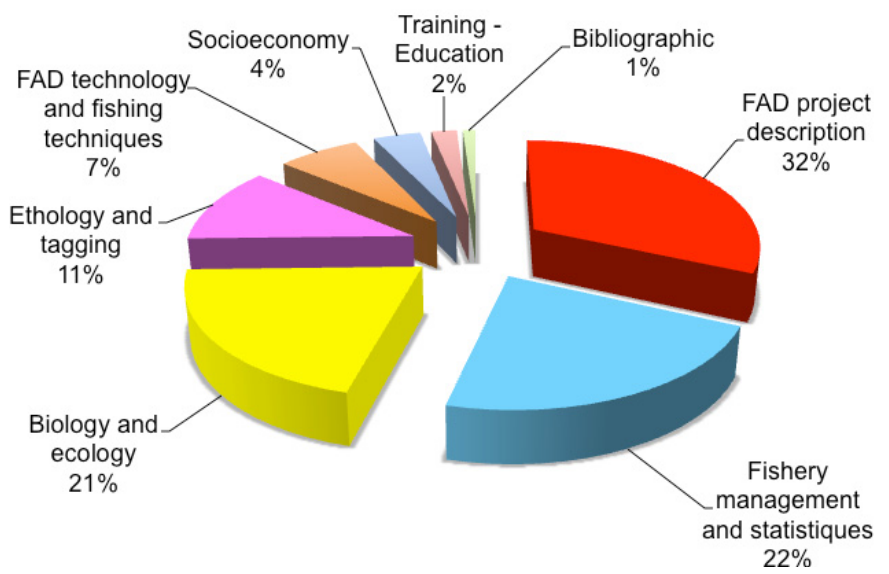

Fig. 4. Proportion of articles by thematic area.

includes reports and conference proceedings (190 ref.). The next two categories are "Fishery management and Statistics" (22\% - 148 ref.) and "Biology and Ecology" (21\% - 134 ref.), which have similar proportions. The "Fishery management and Statistics" category is again mainly composed of grey literature (Reports and Conference proceedings: 108/148 ref.), while the "Biology and Ecology" category is mainly composed of peer-reviewed articles in scientific journals (97/134 ref.). The studies on the behaviour of fish around FADs or logs, using electronic tags or active acoustics, were grouped in the same category, named "Ecology and Tagging", which represents $11 \%$ of the total literature ( 75 ref.) with 55 peerreviewed articles and 20 grey literature works (reports and conference proceedings). This category also includes certain studies using different approaches to help understand fish aggregating behaviour, like the one by Girard et al. (2004) that used mathematic approaches to understand the aggregative behaviour of tagged tuna, or the one by Moreno et al. (2007) where fishermen (purse-seiner captains) were interviewed in order to understand the behaviour of tuna schools around drifting FADs. The last notable category is "FAD technology and Fishing techniques" (7\% - 45 ref.) consisting mainly of grey literature (39/45 ref.) from reports and conference proceedings. Socioeconomic studies remain very poorly represented (4\% - 26 ref.), with only six peer-reviewed articles and 20 grey literature reports and proceedings. Due to the importance of

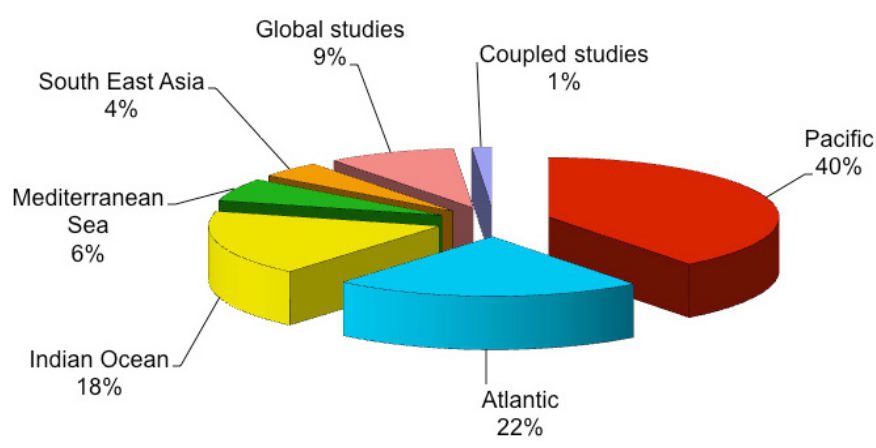

Fig. 5. Proportion of articles by oceanic region.

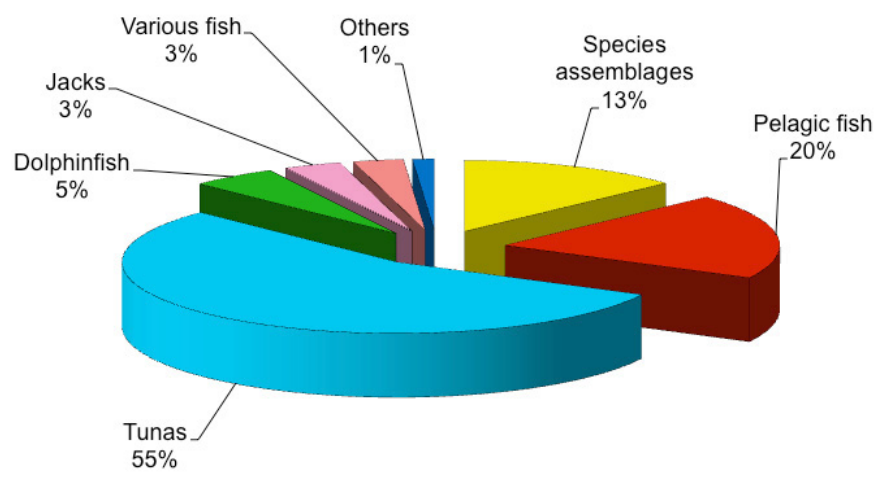

Fig. 6. Proportion of articles by species or group of species.

this field for the sustainable development of FAD fisheries at different scales, socioeconomic studies have become a great priority.

In terms of number of study sites, the Atlantic Ocean is the most important area (Table 1), just before the Pacific. This is mainly due to the many FAD projects developed in the Western Atlantic and, more specifically, in the Caribbean region. In both these parts of the world it is very likely that regional organizations such as The Caribbean Community (CARICOM) or GCFI, and SPC (in the Caribbean and Pacific areas, respectively) have played a major role in the dissemination of information on anchored-FAD projects. In the Indian Ocean, the Indo-Pacific Tuna Programme (IPTP) and the Indian Ocean Tuna Commission (IOTC) have also encouraged meetings between fishers and managers to develop anchored-FAD projects for artisanal fisheries. Intensive development of the use of drifting FADs became more discreet (no references available) under the direct implication of the industrial European tuna fishing fleet and, for the Indian Ocean, by the movement of part of this fleet from the Western Atlantic to this area.

The Pacific Ocean accounts for most references in FADBase (Fig. 5) with 40\% (260 ref.). The SPC plays an important role in the South Pacific (88 ref.) especially in the "Scientific and Technical Reports" category, and it has a very strong influence on anchored-FAD development. However, it is also worth noting the significant efforts made by this organization to disseminate data via its digital library of scientific and technical documents on fisheries, mariculture and the marine environment.

A detailed geographical distribution of the studies allows areas of particular importance to be highlighted, like 
Table 1. Geographical distribution of studies on FADs or the aggregative phenomenon.

\begin{tabular}{|c|c|c|c|}
\hline Atlantic Ocean & Pacific Ocean & Indian Ocean & Mediterranean sea \\
\hline Antigua and Barbuda & Australia & Australia & Balearic Islands (Spain) \\
\hline French West Indies & California (USA) & Mozambique Channel & Spain \\
\hline Brazil & Costa Rica & Minicoy Island & Greece \\
\hline North Carolina (USA) & Colombia & Mauritius & Italia \\
\hline South Carolina (USA) & Fiji & Comoros & Malta \\
\hline Côte d'Ivoire & Gulf of California (Mexico) & India & Sardinia \\
\hline Cuba & Guam & Indonesia & Sicily \\
\hline Curacao & Hawaii (USA) & Reunion Island (France) & Tunisia \\
\hline Florida (USA) & Cook Islands & Madagascar & \\
\hline Ghana & Solomon Islands & Malaysia & \\
\hline Bay of Biscay (France) & American Samoa & Maldives & \\
\hline Gulf of Guinea (Senegal) & Japan & Mascarene Islands & \\
\hline Gulf of Mexico & Kiribati & Mayotte (France) & \\
\hline Grenada & Mariana Islands & Philippines & \\
\hline Guadeloupe (France) & Mexico & Seychelles & \\
\hline Canary Islands (Spain) & Micronesia & Sri Lanka & \\
\hline Azores Islands & Nauru & Tanzania & \\
\hline Cap Verde & Niue & Thailand & \\
\hline Virgin Islands (USA) & New Zealand & & \\
\hline Dominica & Palau & & \\
\hline Louisiana (USA) & Panama & & \\
\hline Martinique (France) & Papua New Guinea & & \\
\hline Mexico & French Polynesia & & \\
\hline Nigeria & Rarotonga & & \\
\hline Portugal & Republic of Naru & & \\
\hline Puerto Rico & Santa Catalina Is. (USA) & & \\
\hline Dominican Republic & Seattle (USA) & & \\
\hline Saint Kitts & Taiwan & & \\
\hline Saint Lucia & Tuvalu & & \\
\hline Saint Vincent and Grenadines & USA & & \\
\hline São Tomé and Príncipe & Vanuatu & & \\
\hline Senegal & Wallis and Futuna & & \\
\hline St Kitts and Nevis & Western Samoa & & \\
\hline \multicolumn{4}{|l|}{ Suede } \\
\hline \multicolumn{4}{|l|}{ Trinidad and Tobago } \\
\hline \multicolumn{4}{|l|}{ USA } \\
\hline Venezuela & & & \\
\hline
\end{tabular}

the Caribbean, South Pacific or Western Indian Oceans (Table 2). However, some studies are not dedicated to a single area; some of them are comparisons between two areas or between different oceans. The similarity between the species lists from data obtained by visual censuses performed under anchored or drifting FADs in different oceanic regions, should encourage comparative studies between international oceans as this would make it possible to develop of specific indices in terms of pelagic diversity (Gaertner et al. 2008). In an era of strong political commitments to implement large offshore Marine Protected Areas, it has become a priority to conduct research using FADs as observatory scientific tools.

Tunas are the main target species around anchored and drifting FADs (Fig. 6). However, other associated species, such as dolphinfish and several species of Carangidae and billfish, may represent a significant proportion of catches. These species are often targeted by artisanal fishers working around anchored FADs, whereas they are by-catch for the industrial purse-seine fisheries working around drifting FADs.

Publications (peer-reviewed articles or grey literature) are mainly on tuna $(55 \%, 259$ ref.), then in order of importance, pelagic fish $(19 \%, 92$ ref.) in the broad sense (without clear species distinction). Studies on species assemblages (from underwater visual censuses or experimental fishing, for example) account for $13 \%$ (62 ref.), followed by those on dolphinfish (5\%, 24 ref.), jacks (3\%, 16 ref.), various species of more marginal fish $(3 \%, 14$ ref.), and sharks $(<1 \%, 3$ ref.). The 
Table 2. Number of references by region.

\begin{tabular}{|c|c|}
\hline Area & No. \\
\hline South East Asia & 29 \\
\hline Western Central Atlantic & 1 \\
\hline Atlantic & 27 \\
\hline North Atlantic & 5 \\
\hline Northwest Atlantic & 5 \\
\hline West Atlantic & 9 \\
\hline Atlantic Ocean & 16 \\
\hline Caribbean & 77 \\
\hline Baltic Sea & 2 \\
\hline Total - Atlantic Ocean & 142 \\
\hline Mediterranean & 34 \\
\hline Eastern Mediterranean & 2 \\
\hline Western Mediterranean & 3 \\
\hline Adriatic Sea & 2 \\
\hline Total - Mediterranean Sea & 41 \\
\hline Indian Ocean & 25 \\
\hline North Indian Ocean & 23 \\
\hline NW Indian Ocean & 1 \\
\hline W Indian Ocean & 39 \\
\hline SE Indian Ocean & 1 \\
\hline SW Indian Ocean & 27 \\
\hline Indian Ocean & 1 \\
\hline Total - Indian Ocean & 117 \\
\hline Pacific Ocean & 47 \\
\hline Central Pacific & 6 \\
\hline Pacific Centre East & 1 \\
\hline Pacific Centre North & 18 \\
\hline Western and Central Pacific & 6 \\
\hline South Pacific Centre & 7 \\
\hline Eastern Pacific & 46 \\
\hline Northeast Pacific & 2 \\
\hline Pacific Northwest & 31 \\
\hline Western Pacific & 12 \\
\hline South Pacific & 68 \\
\hline South West Pacific & 16 \\
\hline Total - Pacific Ocean & 260 \\
\hline Atlantic and Indian Oceans & 1 \\
\hline Pacific and Indian Oceans & 5 \\
\hline Pacific and Atlantic Oceans & 1 \\
\hline Atlantic and Mediterranean & 1 \\
\hline Atlantic, Pacific and Indian & 1 \\
\hline Total - areas coupled & 9 \\
\hline Without geographical allocation & 60 \\
\hline Total & 658 \\
\hline
\end{tabular}

remainder consists of a few studies on marine turtles, seabirds and zooplankton.

From this observation, it is clear that work remains to be done on sensitive marine species, particularly on sharks and sea turtles. The relatively large number of references on species assemblages (62 ref.) corresponds mostly to peerreviewed articles from the indexed scientific literature review.
The number of articles on dolphinfish is relatively high (24 ref.). One of the probable reasons for this attention is that small local fisheries are interested in this species because of its economic value in local markets (Mediterranean, Caribbean, Mascarene Islands, Island States of the South Pacific). It is also a species that displays a strong aggregative behaviour (Dempster and Kingsford 2003; Taquet 2004; Girard et al. 2007; Taquet et al. 2007). The distribution of the references devoted to particular species or groups of species is given (Table 3).

This analysis highlights the lack of historical references between the Roman period and the 20th century. It would be interesting to gain a better understanding of how this fishing tool has been transmitted through the centuries. It is possible that FADs disappeared for some time, but were then reinvented elsewhere. Interesting results could be drawn from a literature search focusing on old fishing books. We consider that scientific conferences significantly improve the production of FAD literature. Experimental studies are still in the minority, despite the recommendations made by several authors (Le Gall et al. 2000b; Freon and Dagorn 2000; Dempster and Taquet 2004; Dagorn et al. 2007). Electronic tagging techniques have progressed and allow data to be collected from tagged fish around FADs, several months after the research vessel has returned to port (Dagorn et al. 2007). Such studies are very expensive to conduct. Archival tags provide good results on large scale studies, e.g., a programme of the Census of Marine Life deployed 4,306 electronic tags on 23 species in the North Pacific Ocean, but high recovery rates of archival tags for bluefin (56\%) and yellowfin (39\%) tunas indicate that high fishery-induced mortality occurs within the California Current large marine ecosystem (Block et al. 2011). However, the archival tags are still too expensive if there is a low rate of return in areas that are not exploited by major fisheries. Two kinds of issues are involved in this expense: (i) the implementation of complex protocols offshore in the open ocean; and (ii) study cost (the long time required using offshore vessels). These observations are even more marked for the study of drifting FADs, whose potential impact on water resources and ecosystems is the highest priority at present. Studying the selectivity of fishing gears or fishing methods used around FADs is essential to eliminate bycatch of sensitive species such as sharks and turtles, but also to minimize bycatch of small bigeye and yellowfin tuna, and non-target species (Gilman 2011).

\section{Conference output and FAD research priorities}

The conference in Tahiti in November 2011 was attended by around 150 participants from 40 countries, three ocean areas and the Mediterranean Sea. Its most innovative aspect was that it brought together fishers, managers and scientists around a common theme. Scientific presentations were devoted to the following five theme-based sessions:

- Artisanal fisheries and anchored FADs.

- Industrial fisheries using anchored or drifting FADs.

- Understanding aggregation.

- Ecosystem impacts of FADs.

- Socioeconomic impacts of FADs. 
Table 3. Number of references by species or group of species.

\begin{tabular}{|c|c|c|}
\hline Fish assemblage & & 62 \\
\hline Pelagic fish & & 92 \\
\hline \multirow[t]{16}{*}{ Tunas } & Tunas & 153 \\
\hline & Thunnus albacares & 46 \\
\hline & Thunnus obesus & 17 \\
\hline & Thunnus albacares and T. obesus & 3 \\
\hline & Thunnus atlanticus & 5 \\
\hline & Thunnus maccoyii & 2 \\
\hline & Thunnus thonggol & 1 \\
\hline & Thunnus thynnus & 1 \\
\hline & Katsuwonus pelamis & 24 \\
\hline & Acanthocybium solandri & 1 \\
\hline & Scomberomorus cavalla & 1 \\
\hline & Tunas and dolphins & 2 \\
\hline & Tunas and bycatch & 1 \\
\hline & Tunas and squid & 1 \\
\hline & Tunas and seabirds & 1 \\
\hline & Total Tunas & 259 \\
\hline Dolphinfish & Coryphaena hippurus & 24 \\
\hline \multirow[t]{12}{*}{ Jacks } & Atule mate & 3 \\
\hline & Caranx crysos & 1 \\
\hline & Decapterus sp. & 1 \\
\hline & Naucrates ductor & 4 \\
\hline & Pseudocaranx dentex & 1 \\
\hline & Selar crumenophthalmus & 1 \\
\hline & Seriola dumerili & 1 \\
\hline & Seriola fasciata & 1 \\
\hline & Seriola lalandi & 1 \\
\hline & Seriola quinqueradiata & 1 \\
\hline & Trachurus japonicus & 1 \\
\hline & Total Jacks & 16 \\
\hline \multirow[t]{3}{*}{ Sharks } & Carcharhinus falciformis & 2 \\
\hline & Rhincodon typus & 1 \\
\hline & Total Sharks & 3 \\
\hline \multirow[t]{3}{*}{ Marlins } & Istiophoridae & 1 \\
\hline & Makaira nigricans & 1 \\
\hline & Total Marlins & 2 \\
\hline \multirow[t]{9}{*}{ Various Fish } & Lobotes surinamensis & 1 \\
\hline & Polyprion americanus & 2 \\
\hline & Liza dumerili & 1 \\
\hline & Pollachius virens & 1 \\
\hline & Brama orcini & 1 \\
\hline & Cypselurus spp. & 1 \\
\hline & Epinephelus sp. & 1 \\
\hline & Mullidae & 1 \\
\hline & Total Various Fish & 9 \\
\hline \multirow[t]{3}{*}{ Seabirds } & Seabirds & 2 \\
\hline & Puffinus mauretanicus & 1 \\
\hline & Total seabirds & 3 \\
\hline Sea Turtles & Sea turtles & 2 \\
\hline \multirow[t]{2}{*}{ Zooplankton } & Zooplankton & 1 \\
\hline & TOTAL & 473 \\
\hline
\end{tabular}

The final two days featured 4 round table discussions led by expert panels (four to five experts for each discussion), who had direct interaction with all participants and were based on the following priority issues: (1) anchored-FAD design and technology: durability and effectiveness; (2) socioeconomic impact and management of regional FAD programmes; (3) the drifting-FAD: How to manage this very effective tool? (4) research on anchored and drifting FADs. The expert panel's formal and complete summary (Taquet et al. 2011) is available for download at: spc-fisheries-newsletter-136.html.

\subsection{Anchored-FAD design and technology: durability and efficiency}

There are different types of components and design for each FAD type (lagoon, coastal surface, coastal subsurface, offshore). In recent years, the technological trend has been to reduce the number of components (e.g., swivels, shackles) in the mooring lines to avoid "weak links". In general, the use of heavy anchors or concrete blocks avoids slippage problems on the bottom; however, the use of lighter anchoring systems (grapples) is more common for coastal FADs, particularly when there is no support vessel of sufficient size to lay large anchors. The use of stainless steel fittings and cables is not necessary, although it is used successfully in some sites (Maldives). Opinions differ as to whether or not maintenance programmes are necessary. For single float FADs (spherical buoy) equipped with position transmitters, regular maintenance may not be necessary or profitable. On the other hand, the "Indian Ocean" FAD type made of small floats requires regular and frequent maintenance. Being able to obtain realtime data on the state of a FAD is considered a great advantage, especially for fishers. On coastal and offshore FADs, fishers still prefer to use "aggregators" although there is no scientific data confirming their necessity. However, large structures seem to be more effective than smaller ones. Use of aggregators separated from the anchor line, like in the Maldives' FADs, may be more effective. These appendages can then be used as a stabilizer for the FAD's main float. Decisions made on the FAD's anchor location must always involve different user groups (fishers, recreational fishers) to avoid conflicts of use. In some cases, the FAD may serve to reduce these conflicts, but these issues can also be solved by the implementation of local regulations. For all types of FAD, it is essential to develop data collection (biological, statistical, socioeconomic) networks to quantify the impact (usually deemed a positive one) of FAD projects. These data are also essential to promote and ensure the successful acquisition of financial support for FAD projects. In the field of small-scale fisheries using FADs, testing new ideas, such as the "unanchored stationary FAD" is an area worthy of further study. There is a growing demand for the small lagoon FAD, particularly in rural areas, where it can be combined with the creation of Marine Protected Areas (MPAs) to strengthen food security. The effectiveness of this type of FAD is often related to the nature of the sites; sandy lagoons are often good sites that promote the concentration of small pelagic fish. Furthermore, this type of device is inexpensive and can be manufactured according to many models with a variety of building materials. 
Inshore FADs are seen as effective tools to achieve a number of objectives: food security; reducing fishing pressure on reef areas; and combating the impacts of global change. These devices are typically inexpensive (less than US\$ 2000). It would be useful to conduct a comparative study (lifespan/cost) on several models of recently deployed inshore FADs.

Subsurface FADs are booming in popularity, as they have many advantages, such as the lessened vandalism issues, their particular suitability for areas of heavy maritime traffic, and their increased lifespan, which is due to the reduction of waveand storm-related wear. Furthermore, they are often cheaper for equivalent immersion depths. However, there are currently some technical limitations on the possible depths for the deployment of subsurface FADs. In general, the fishers were not very favourable to this type of FAD at the beginning (lack of surface reference, difficulties in detecting its position, accidental hooking possible with vertical longlines, etc.). However, these viewpoints evolved quickly when good fisheries were conducted under the FAD. Deployment can be difficult in deep water as these conditions require a high accuracy for installation, special equipment (depth sounder) and a calm sea. The upper part of the FAD can also go beneath its effective depth zone in strong currents. Nevertheless, there are several examples of successful FAD use at depths of up to $500 \mathrm{~m}$ (Tonga, Fiji), but questions remain about maximum implementation depth, which is an area requiring further investigations. Theoretical studies using numerical models, such as the Ifremer software "FAD" (Dynaline - Priour and Lebeau 1999) could help progress on subsurface FADs located offshore in deep waters $(>1500 \mathrm{~m})$. While surface FADs are the most realistic option for offshore areas, there is a growing interest in the implementation of subsurface FADs in deep waters.

For offshore FADs, the use of mixed cables (steel/polyamide or steel/polypropylene) for the upper part of the mooring line (first $300 \mathrm{~m}$ ) seems very appropriate and effective (particularly against cuts caused by fishing lines and fish bites). Currently, mixed cables are gradually replacing conventional rope in offshore FAD design. "Dual head" FADs appear to be very effective for fish aggregation as they reduce FAD loss to facilitate maintenance and increase FAD lifespan, but increased monitoring is necessary for these benefits to be sustained.

\subsection{Socioeconomic impact and management of regional FAD programmes}

At the socioeconomic level, it is commonly accepted that anchored FADs can assist in the development of small-scale fisheries production and increase exports. They reduce fishing costs and, in some countries, contribute to food security and the maritime safety of fishers. In some cases, FADs become a cultural tool, enabling groups of fishers to organize themselves better.

The FAD can be a management tool that helps fishing communities to limit the negative impacts of climate change.

It may protects reef and lagoon resources by transferring the fishing effort to pelagic species that are less sensitive to fishing pressure. Catches of pelagic fish around FADs may be a solution for small-scale fisheries to limit the negative impact caused by increased ciguatera incidence in many tropical regions. As regards access regulations to FADs, these vary widely between different countries, with cases of completely open access, restricted access for professional fishers only, or various regulations depending on user status. The conflict of use issue was discussed during the 2011 conference. Control systems based on the fishers themselves, such as Prud'homies (fishers' local self-regulatory bodies) were highlighted as an example of efficiency. The issue of the sale of fish caught by recreational fishers around FADs is a potential source of conflict. There is a growing need to develop management measures involving stakeholder input from all sectors to ensure that management measures are accepted and enforceable. Once again, the use of self-regulation by the users themselves seems to be the most effective method. There are still questions surrounding the ownership of resources aggregated around a FAD, ranging from the act of fishing itself, to paying for FAD access. The concept of privatization of the public maritime domain is a very sensitive issue in many countries and involves several user groups who can claim different rights (professional or recreational fishers and boat users, divers, associations, etc.). In some cases, specific trading initiatives are emerging for the marketing of fish from anchored-FAD fisheries (green label). With the image of healthy pelagic fish, captured offshore, far from coastal contamination and free from pesticide-related problems or ciguatera. Among the recommendations made during this roundtable, it was recognized that access issues are complex and must be managed at the local level. In some regions, access conflicts among FAD user groups are a genuine concern that requires the intervention of an impartial public manager with the ability to coordinate communication and management efforts. FAD fishing data collection should be implemented at the beginning of FAD programs and continuously pursued in order to obtain a robust and accurate CPUE analysis. Cost-benefit analyses and costeffectiveness studies should be carried out from these CPUE data and from other good socioeconomic data in order to gauge the importance of the FADs for artisanal fishers. FAD projects must now include a reflection on innovative funding methods which may include contributions from the various user groups through taxes or access permits/funds derived from fines collected during fishing infractions at different scales. The issue of anchored-FAD density was addressed in connection with a possible productivity loss (separation distances between devices) while it was noted that the increased numbers of anchored FADs in the same area allowed to partially mitigate conflicts. An impact assessment of these fisheries is essential; however, some technical difficulties were highlighted such as how to define and measure FAD fishing effort. Discussions took place about funding-related issues for such monitoring and to promote the use of standardized reporting and evaluation methods. A proper evaluation of the minimum requirements is required, including an acceptable level of uncertainty to minimize data collection costs. Various funding sources for FAD projects were covered: taxes on fishing gear and activities, permits based on the "user pays" principle, private and international organization funding, and development funds 
collected out of money received from the sale of fishing rights to foreign fleets. On these aspects, the recommendations focused on finding long-term alternative and sustainable solutions regarding funding sources to promote these FADs, which should also promote the direct and indirect socioeconomic cost-benefit analysis of anchored FADs.

\subsection{Drifting-FADs: How to manage this very effective tool?}

Over the last decade, significant progress has been made by the fishing industry in reducing the negative impacts of drifting FAD fisheries. Steps include:

- Minimizing bycatch of sea turtles, small tuna and other non-target pelagic fish through the use of sonar buoys, acoustic selectivity and the new drifting-FAD design "Eco-FAD" to reduce the entanglement of sharks and sea turtles.

- Implementing research programs that limit and mitigate bycatch generated by drifting FAD fisheries.

There is an urgent need to develop research programmes on the specific use of drifting FADs by industrial fisheries, with a focus on the following aspects:

- Gaining a deeper understanding and a more detailed knowledge of technical data on drifting FADs (number of electronic buoys deployed, number of rafts used and their trajectories, number and size of boats involved in these fisheries, number of sets, launch procedures, ownership, FAD recovery, etc.). It has been reported that nowadays, "FAD Supply vessels" must provide detailed logbooks that can be analyzed to provide such information. Similarly, effective management of drifting FADs was another urgent need identified. This could lead to limitation of the number of active buoys by ship or by fleet.

- Developing changes in different types of drifting FADs, fishing gear used, and fishing strategies, to reduce nontarget catches, including taking measures that could lead to the reduction in fishing efficiency such as the prohibition of "supply vessels".

- Testing the establishment of catch limits for certain species at fleet or ship levels to reduce bycatch.

- Encouraging collaboration and data exchange between the fishing industry and managers, in order to obtain valid data that enable the calculation of reliable CPUE and an assessment of the real impact of drifting FADs.

- Developing standardized drifting-FAD management plans containing the necessary field data for effective management to be achieved.

Meanwhile, the conference highlighted that drifting FADs significantly improve the economic performance of a fishery through (potential) savings in time and fuel, reduce operating costs, and improve the yields and expansion of fishing areas. FADs are essential for fisheries working in areas where free schools are very seasonal. It is highly important to develop technical solutions to minimize the negative impacts of these powerful tools.

\subsection{Research priorities for anchored and drifting FADs}

Analysis of the literature on anchored and drifting FADs produced over the last few decades, along with fruitful discussions with the panel of experts present at the FAD Conference in Tahiti, enabled the identification of research priorities that are largely shared by the whole FAD community (scientists, fishers and managers). We recommend the development of instrumented FADs with a wide range of scientific equipment (sounder, scientific underwater camera, sound and environmental parameters recorders, new electronic tags, etc.). Instrumented FADs could be widely deployed in research projects conducted in close collaboration with the fishing industry. They could be used in well-selected study areas, such as the Mozambique Channel, or in areas with a FAD moratorium (during and after the moratorium).

It is recommended that the moratorium on FADs implemented by Regional fisheries management organizations (RFMOs) be associated with scientific research to monitor the dynamics of tunas aggregated before, during and after the moratorium period, and that instrumented FADs and research/fishing vessels be used in the moratorium area. It is also recommended to conduct comparative analyses of the stomach content of tunas (free schools versus schools associated with FADs) in several regions of the world. These results are of major importance to assess the impact of drifting FADs on ecosystems, to understand the interactions between the different species (i.e., tuna natural mortality) and to quantify diversity in offshore pelagic areas.

Recommendations were made to reduce pollution levels from lost FADs (sunken or stranded on the coast) to a level close to zero. In accordance with MARPOL (International Convention for the Prevention of Pollution from Ships), it is envisaged that FAD owners could become responsible for their recovery. Otherwise, biodegradable FADs could be developed by researchers and fishers and their use could be promoted rapidly. Further recommendations were made to find ways to pre-estimate catch composition (bycatch ratio/targeted catch), reduce bycatch, and study the survival rate of released fish with a specific focus on sharks. Industrial fishers should cooperate fully with scientists to share their data (acoustic data, FAD localization) in order to gain a deeper understanding of FAD dynamics and of their impacts on ecosystems. It is recommended that more comparative studies be conducted by scientists, between the oceans and through different regions of the world around anchored and drifting FADs, since comparative studies are essential to gain a better understanding of the biological processes and mechanisms involved in the aggregative phenomenon. One possibility could be to create an online network of scientists involved in FAD research, which would be a first step to facilitating international cooperation on this issue. Research also needs to be conducted on anchored-FAD design in order to significantly increase lifespan to optimize investment and develop subsurface FADs in deeper offshore areas.

It is recommended to monitor biological variables (catch by species and size, effort, etc.) and conduct economic surveys (catch prices, fishing operation costs, etc.): essential components in assessing the impact that FADs have on resources and in analyzing socioeconomic gains. This background information is important to successfully obtain funding for the 
implementation of FAD projects. Standardized sampling methods for data collection must be developed and implemented.

\section{Supplementary content}

Acknowledgements. The "Tuna Fisheries and FADs" International Conference received funding from Pacific Funds of the French Ministry for the Foreign Affairs (Ministère français des Affaires étrangères), the Ministry of Marine Resources of French Polynesia, French Ministry of Higher Education and Research (Ministère de l'Enseignement supérieur et de la Recherche), the General Delegation for Overseas affairs during the Year of French Overseas Regions (Année des Outre-mer), the Secretariat of the Pacific Community (SPC), the Tahiti Fa'ahotu innovative cluster, the French research institutes: IRD and Ifremer. The author wishes to thank Olivier Dugornay for his skillful technical assistance in the video clip.

\section{References}

Anderson J., Gates P.D., 1996, South Pacific Commission Fish Aggregating Device (FAD) manual, Volume1, Planning FAD programmes. Coastal Fisheries Programme, CPS, Nouméa (French version: 1997).

Bergstrom M., 1983, Review of experiences with and present knowledge about fish aggregating devices. Bay of Bengal Programme, Development of Small-Scale Fisheries. FAO Report BOBP/WP/23.

Block B.A., Jonsen I.D., Jorgensen S.J., Winship A.J., Shaffer S.A., Bograd S.J., Hazen E.L., Foley D.G., Breed G.A., Harrison, A.L., et al., 2011, Tracking apex marine predator movements in a dynamic ocean. Nature 475, 86-90.

Dagorn L., Pincock D., Girard C., Holland K., Taquet M., Sancho G., Itano D., Aumeeruddy R., 2007, Satellite-linked acoustic receivers to observe behavior of fish in remote areas. Aquat. Living Resour. 20, 307-312.

Dempster T., Kingsford M.J., 2003, Homing of pelagic fish to fish aggregating devices (FADs): an investigation of the role of sensory cues. Mar. Ecol. Prog. Ser. 258, 213-222.

Dempster T., Taquet M., 2004, Fish aggregation device (FAD) research: gaps in current knowledge and future directions for ecological studies. Rev. Fish Biol. Fish. 14, 21-42.

Desurmont A., Chapman L., 2000, The use of anchored FADs in the area served by the Secretariat of the Pacific community (SPC): Regional synthesis. In: Le Gall J.Y., Cayré P., Taquet M. (eds), Pêche thonière et dispositifs de concentration de poissons. Ifremer, Actes Colloq. 28, pp. 108-140.

Dickson J.O., Natividad A.C., 2000, Tuna fishing and a review of "payao" in the Philippines. In: Le Gall J. Y., Cayré P., Taquet M. (eds), Pêche thonière et dispositifs de concentration de poissons. Ifremer, Actes Colloq. 28, pp. 141-158.

Fonteneau A., 1973, La pêcherie des thons tropicaux dans l'Atlantique, le rôle de l'ORSTOM. Pêche Marit. 1143, 443-445.

Fonteneau A., Pallares P., Pianet R., 2000, A worldwide review of purse seine fisheries on FADs. In: Le Gall J.Y., Cayré P., Taquet M. (eds), Pêche thonière et dispositifs de concentration de poissons. Ifremer, Actes Colloq. 28, pp. 15-34.

Fréon P., Dagorn L., 2000, Review of fish associative behaviour: toward a generalisation of the meeting point hypothesis. Rev. Fish Biol. Fish. 10, 183-207.

Gaertner J.C., Taquet M., Dagorn L., Mérigot B., Aumeeruddy R., Sancho G., Itano D., 2008, Visual census around drifting fish aggregating devices (FADs): an innovative approach for assessing the diversity of fish in open-ocean waters. Mar. Ecol. Prog. Ser. $366,175-186$.
Galea J.A., 1961, The 'Kannizzati' Fishery. Proc. Gen. Fish. Counc. Med. 55, 85-91.

Gilman E.L., 2011, Bycatch governance and best practice mitigation technology in global tuna fisheries. Mar. Policy 35, 590-609.

Girard C., Benhamou S., Dagorn L., 2004, FAD: Fish Aggregating Device or Fish Attracting Device? A new analysis of yellowfin tuna movements around floating objects. Anim. Behav. 67, 319-326.

Girard C., Dagorn L., Taquet M., Aumeeruddy R., Peignon C., Benhamou S., 2007, Homing abilities of dolphinfish (Coryphaena hippurus) displaced from fish aggregating devices (FADs) determined using acoustic telemetry. Aquat. Living Resour. 20, 313-321.

Hall M.A., 1998, An ecological view of the tuna - dolphin problem: impacts and trade-offs. Rev. Fish Biol. Fish. 8, 1-34.

Holland K.N., Jaffe A., Cortez W., 2000, The fish aggregating device (FAD) system of Hawaii. In: Le Gall J.Y., Cayré P., Taquet M. (eds), Pêche thonière et dispositifs de concentration de poissons. Ifremer, Actes Colloq. 28, pp. 55-62.

Jones J., 1722, Oppian's Halieuticks of the Nature of Fishes and Fishing of the Ancients. Translated from the Greek, Oxford, printed at the Theater, 3506 verses, in V books.

Kakuma S., 2000, Synthesis on moored FADs in the North West Pacific region. In: Le Gall J.Y., Cayré P., Taquet M. (eds), Peche thonière et dispositifs de concentration de poissons. Ed. Ifremer, Actes Colloq. 28, pp. 63-77.

Le Gall J.Y., Cayré P., Taquet M., 2000a, Mechanisms and effects of the aggregation of tuna by Fish Aggregating Devices (FADs). Aquat. Living Resour. 13, 181 (Editorial).

Le Gall J.Y., Cayré P., Taquet M., 2000b, Pêche thonière et dispositifs de concentration de poissons. Ifremer. Actes Colloq. 28.

Limes J.M., 1817, Les Halieutiques, la pêche et les moeurs des habitants des eaux. Traduction en français des poèmes d'Oppien. Lebrégue, Imprimeur-Libraire, Paris, 3506 vers, 5 chants.

Lennert-Cody C.E., Hall M.A., 2000, The development of the purse seine fishery on drifting aggregating devices in the Eastern Pacific Ocean: 1992-1998. In: Le Gall J.Y., Cayré P., Taquet M. (eds), Pêche thonière et dispositifs de concentration de poissons. Ifremer, Actes Colloq. 28, pp.78-107.

Marcille J., Bour W., 1981, La pêche des thons à la senne et à la canne dans l'océan Pacifique tropical : situation actuelle et perspectives de développement. Editions de l'Orstom, Paris.

Morales-Nin B., Cannizzaro L., Massuti E., Potoschi A., Andaloro F., 2000, An overview of the FADs fishery in the Mediterranean Sea. In: Le Gall J.Y., Cayré P., Taquet M. (eds), Pêche thonière et dispositifs de concentration de poissons. Ifremer, Actes Colloq. 28, pp. 184-207.

Moreno G., Dagorn L., Sancho G., Garcia D., Itano D., 2007, Using local ecological knowledge (LEK) to provide insight on the tuna purse seine fleets of the Indian Ocean useful for management. Aquat. Living Resour. 20, 367-376.

Pianet R., 1973, Le rôle de l'ORSTOM de Pointe-Noire dans la recherche thonière. Pêche Marit.1143, 448-451.

Preston G.L.,1991, Fish aggregation devices in the Pacific Islands region. Symp. Artificial Reefs and Fish Aggregating Devices as tools for the management and enhancement of marine fishery resources, Colombo, Sri Lanka, 14-17 May 1990. Rapa Report 1991/11, pp. 279-294.

Priour D., Lebeau A., 1999, Progiciel « Dynaline». Direction de la technologie marine et des systèmes d'information (TMSI), Ifremer, Brest.

Reynal L., Van Buurt G., Taquet M., 2000, Prospects for the development of anchored FADs in the Lesser Antilles. The case of three 
islands: Guadeloupe, Martinique and Curacao. In: Le Gall J.Y., Cayré P., Taquet M. (eds), Pêche thonière et dispositifs de concentration de poissons. Ifremer, Actes Colloq. 28, pp. 36-54.

Stéquert B., Marsac F., 1991, Pêche thonière à la senne : évolution de la technique et bilan de dix années d'exploitation dans l'océan Indien. Editions ORSTOM, Paris.

Taquet M., 2004, Le comportement agrégatif de la dorade coryphène (Coryphaena hippurus) autour des objets flottants. Thèse doctorat Univ. Pierre et Marie Curie, Paris 6, Océanologie biologique et environnement marin.

Taquet M., Sancho G., Dagorn L., Gaertner J. C., Itano D., Aumerruddy R., Wendling B., Peignon C., 2007, Characterizing fish communities associated with drifting fish aggregating devices (FADs) in the Western Indian Ocean using underwater visual surveys. Aquat. Living Resour. 20, 331-341.
Taquet M., Blanc M., Dagorn L., Filmalter J., Fonteneau A., Forget F., Gaertner J.C., Galzin R., Gervain P., Gougon M., Guillotreau P., Guyader O., Hall M., Holland K., Itano D., Monteagudo J.P., Morales-Nin B., Reynal L., Sharp M, Sokimi W., Tanetoa M., Yen Kai Sun S., 2011, Artisanal and industrial FADs: A question of scale. Tahiti conference reviews current FAD use and technology. SPC Fish. Newslett. 136, 35-45.

Tessier E., Rey-Valette H., Ah-Nieme D., Bargain R.M., Venkatasamy A., Wendling B., 2000, Halieutic systems and FADs in the Indian ocean: a review of the various trials carried out and the results obtained in terms of integration and overall benefits. In: Le Gall J.Y., Cayré P., Taquet M. (eds), Pêche thonière et dispositifs de concentration de poissons. Ifremer, Actes Colloq. 28, pp. 159-183. 